\title{
Incidence of medication errors and adverse drug events in the ICU: a systematic review
}

\author{
Amanda Wilmer, ${ }^{1,2}$ Kimberley Louie, ${ }^{1,2}$ Peter Dodek, ${ }^{1,2,3}$ Hubert Wong, ${ }^{3}$ \\ Najib Ayas ${ }^{1,2,4,5}$
}

${ }^{1}$ Program in Critical Care Medicine and the Department of Medicine, Providence Health Care, Vancouver, British Columbia, Canada

${ }^{2}$ Department of Medicine University of British Columbia, Vancouver, British Columbia, Canada

${ }^{3}$ Center for Health Evaluation and Outcome Sciences,

Vancouver, British Columbia, Canada

${ }^{4}$ Respiratory Division, Vancouver General Hospital, Vancouver British Columbia, Canada ${ }^{5}$ Center for Clinical Epidemiology and Evaluation, Vancouver Coastal Health Research Institute, Vancouver, British Columbia, Canada

\section{Correspondence to}

Dr Najib Ayas, 224 Comox Building, St Pauls Hospital, 1081 Burrard Street, Vancouver, BC V6Z 1Y6, Canada:

nayas@providencehealth.bc.ca

Accepted 20 April 2009 Published Online First 29 July 2010

\section{ABSTRACT}

Background Medication errors (MEs) and adverse drug events (ADEs) are both common and under-reported in the intensive care setting. The definitions of these terms vary substantially in the literature. Many methods have been used to estimate their incidence.

Methods A systematic review was done to assess methods used for tracking unintended drug events in intensive care units (ICUs). Studies published up to 22 June 2007 were identified by searching eight online databases, including Medline. In total, 613 studies were evaluated for inclusion by two reviewers.

Results The authors selected 29 papers to analyse; all studies took place in an ICU, were reproducible and reported ICU-specific rates of events. Rates of MEs varied from 8.1 to 2344 per 1000 patient-days, and ADEs from 5.1 to 87.5 per 1000 patient-days. The definitions of $\mathrm{ADE}$ and $\mathrm{ME}$ in the studies varied widely.

Conclusions Much variation exists in reported rates and definitions of ADEs and MEs in ICUs. Some of this variation may be due to a lack of standard definitions for ADEs and MEs, and methods for detecting them. Further standardisation is needed before these methods can be used to evaluate process improvements.

\section{INTRODUCTION}

The rate of medication errors (MEs) and adverse drug events (ADEs) for patients admitted to the intensive care unit (ICU) is greater than that for patients admitted to general medical wards ${ }^{1}$ for several reasons. First, ICU patients receive more medications than patients on other hospital wards. ${ }^{12}$ Second, most medications in the ICU are given intravenously, and calculation of infusion rates is often required; both of these characteristics may create more opportunities for error. ${ }^{2}$ Third, most patients in the ICU are sedated and are therefore unable to identify potential errors themselves. ${ }^{2}$ Fourth, patients in the ICU have little physiological reserve, potentially increasing risks of harm from medication-related errors. It is thus important to have methods to accurately measure rates of MEs and $\mathrm{ADE}$ in the ICU.

The Institute of Medicine (IOM) provides definitions for MEs and ADEs. ${ }^{3} \mathrm{MEs}$ are any errors occurring in the medication-use process. Examples of this are wrong dosage prescribed or wrong dosage administered. ${ }^{3}$ An ADE refers to any injury due to a medication. ${ }^{3}$ Although ADEs are often caused by errors, this term does not necessarily mean that an error occurred; an example of this is a patient in whom an allergic reaction to a drug occurred who was not known to have any allergies. ${ }^{3}$ A preventable
$\mathrm{ADE}$ occurs when an $\mathrm{ADE}$ results from a preventable $\mathrm{ME}$ (ie, any error in the prescribing or transcribing of a medication order, or in the dispensing, administration or monitoring of a medication). ${ }^{4}$

Many different definitions and methods for tracking MEs or ADEs have been used in the ICU setting. The purpose of our study was to systematically review the published literature regarding MEs and ADEs that occur in the ICU, specifically highlighting the differences in event rates as a function of the terms used to define events and the techniques used for detection.

\section{METHODS}

\section{Literature search}

We searched for all relevant studies published before 22 June 2007, when the final search took place. Studies were identified using Medline (1950-present), Embase (1980-present), Biosis (1969-present), CINAHL (1982-present), IPA (1970-present), DARE (1996-present), CDSR (1995-present) and ACP Journal Club (1991-present) Databases.

For the Medline search, we used the following strategy: MeSH terms 'intensive care units' and 'intensive care' and multipurpose words 'intensive care' and 'icu\$' were used. To identify a wide range of methods for collection of MEs, MeSH terms 'medication errors' and 'adverse drug reaction reporting systems' were used. Also, multipurpose terms '((medication or drug or prescri\$) adj2 (error\$ or mistake\$)), (incident\$ or voluntary\$) adj2 report \$' and 'adverse drug event\$' were used. The ultimate search strategy was the union of ICU terms and the ME terms. The search was restricted to articles published in English. Comparable searches were run in the other databases.

\section{Inclusion/exclusion criteria}

To be included, studies had to take place in an ICU, have original data, describe a method of measuring $\mathrm{MEs}$ or $\mathrm{ADEs}$, include a rate of $\mathrm{ME}$ or $\mathrm{ADE}$ occurrence, and have sufficiently detailed methods so that the study could be replicated. Articles were excluded if they did not provide numerical ME or $\mathrm{ADE}$ rates, or if the rates provided were pooled with wards other than the ICU. We also excluded abstracts from conferences, letters, comments, opinion pieces and editorials.

All abstracts were reviewed by two investigators (AW and KL). Full manuscripts of any potentially eligible studies were obtained. Any disagreements in each round were resolved by discussion between the two reviewers and evaluation by the senior authors (PD and NA) as necessary. 


\section{Data abstraction}

Study data were grouped by the methods used to detect MEs or ADEs. Voluntary reporting systems involved ICU staff using a paper or computer-based system to provide details of a potential or actual unintended medication events. Prescription review involved a pharmacist reviewing medication orders and documenting errors found. Observational techniques involved a trained observer following a prescription for some portion of the process from when it was written to its administration to examine the process for errors. Trigger tools involved a review of patient records, with either chart review or computer programs for evidence of indications of ADEs such as antidote use, or electrolyte abnormalities that could be due to medications. Multifaceted methods combined several of the aforementioned techniques.

Information was collected on the type of ICU studied, the country in which the study took place, the type of hospital (academic vs community), the number of centres involved, the definition of events measured, the methods used to detect events and the event rates detected.

In studies involving more than one ICU or where a pre-post design was used, weighted averages were calculated for each individual study when possible to provide a single rate of MEs or ADEs per 1000 patient-days. This was done by multiplying the rate for each separate group by the fraction of the total number of patient-days examined in that group. The rates were then added together to obtain an overall weighted average. Studies with the same units of measurement (eg, $\mathrm{ADE} / 1000$ patientdays) were grouped together for comparison.

\section{RESULTS}

The initial literature search yielded 613 abstracts. After review of these abstracts, 174 full articles were obtained. Forty-five articles were excluded because they did not have original data, 37 because they did not report relevant outcomes, 14 because the severity of the events was not reported, four because results combined ICU and non-ICU specific data, four because the methods did not provide enough information to replicate the study and 41 for two or more of the above reasons. In the end, 29 articles remained for analysis. ${ }^{15-32}$

All of the studies came from first-world countries, and most $(24 / 29)$ took place in an academic tertiary care hospital (table 1). Specifics of the durations of studies, countries of origin, types of ICUs and methods of study are summarised in table 1.

The studies were grouped by the outcome reported (eg, ADEs, preventable $\mathrm{ADEs}$ ) as shown in tables $2-5$. The predominant methods of event detection in the studies were prescription review $(n=7)$ and multifaceted techniques $(n=7)$, followed by observational techniques $(n=6)$, voluntary reporting $(n=5)$, trigger tools $(n=3)$ and comparison of two of the previously mentioned methods $(n=1)$. The majority of these studies had different definitions of the events being measured. There was substantial variability in event rates, regardless of the specific outcome; in general, there was a one to two order of magnitude difference in rates across studies even when the same type of event was reported. For instance, the range of $\mathrm{ADE} / 1000$ patientdays ranged from 2.4 to 87.5 (table 2)..$^{15-12}$ Not unexpectedly, $\mathrm{MEs}$ were more common than $\mathrm{ADEs}$, and more events were identified when multifaceted methods of detection were used.

\section{DISCUSSION}

We found a wide variation in reported rates of medicationrelated events. We believe that much of this large variability was
Table 1 Characteristics of studies included

\begin{tabular}{|c|c|}
\hline \multicolumn{2}{|l|}{ Type of hospital } \\
\hline \multicolumn{2}{|c|}{ Academic/tertiary referral centre $=24$} \\
\hline \multicolumn{2}{|l|}{ Community $=1$} \\
\hline \multicolumn{2}{|l|}{ Mixed =1 } \\
\hline \multicolumn{2}{|l|}{ Unspecified $=3$} \\
\hline Country of origin & Type of ICU studied \\
\hline USA $=17$ & Medical ICU $=2$ \\
\hline $\mathrm{UK}=4$ & Surgical ICU $=1$ \\
\hline Australia $=1$ & Paediatric $\mathrm{ICU}=4$ \\
\hline Canada $=2$ & Neonatal ICU=1 \\
\hline \multirow[t]{4}{*}{ Other $=5$} & Mixed ICU $=6$ \\
\hline & 0 ther $=2$ \\
\hline & $>1$ of above $=11$ \\
\hline & Unspecified $=2$ \\
\hline No of centres in each study & Length of study \\
\hline $1=22$ & $\leq 1$ month $=9$ \\
\hline $2=3$ & $>1-12$ months $=14$ \\
\hline$\geq 3=4$ & $>1$ year $=6$ \\
\hline Method of error detection & No of ICU beds studied \\
\hline Observation $=6$ & $1-10=2$ \\
\hline Prescription review $=7$ & $11-20=10$ \\
\hline Multifaceted $=7$ & $21-30=3$ \\
\hline Voluntary reporting $=5$ & $>30=7$ \\
\hline Trigger tool $=3$ & Unspecified $=7$ \\
\hline Two methods compared $=1$ & \\
\hline
\end{tabular}

due to differences in: (1) definitions of the same type of event and (2) methods used to detect events.

\section{MEs compared with ADEs}

MEs include any error from prescribing through to administration and monitoring of a drug but which do not necessarily cause harm. Conversely, ADEs indicate that patient harm has occurred. Because most MEs do not result in harm, it is logical that MEs are more frequent than ADEs. To illustrate this, Rothschild et al found the rate of MEs to be 129.5/1000 patientdays, while the rate of ADEs was only 37.6/1000 patient-days. ${ }^{12}$

Although MEs do not lead to harm in many cases, they provide the unique opportunity to identify the need for system changes, which have the potential to prevent harm to patients. Measuring $\mathrm{ADE}$ rates is also useful, since this identifies actual situations in which patients are harmed and also allows for change for safer policies.

\section{Variability in definitions of events}

Another reason for variability among the studies was the diversity of definitions used for the same type of event. For example, 14 studies included in this paper reported MEs per 1000 patientdays as an outcome (table 3). ${ }^{1} 7812$ 16-25 Two of these studies provided no definitions for this term, while the 12 other studies each used a different definition. Some studies focused on only one aspect of the medication process (eg, prescribing or administration), while others focused on all aspects. Nevertheless, even in the 10 studies that looked at all aspects of the process, there was still substantial variation in the definitions of MEs among these studies (table 3). ${ }^{1} 812$ 16-22 Some authors defined MEs similar to how we have done (errors in drug prescribing, transcription, dispensing, administration and monitoring), $812{ }^{21}$ while other authors provided more vague definitions such as "potential or 
Table 2 Description of studies that presented rates of adverse drug events (ADE) per 1000 patient-days, potential adverse drug events (PADEs) per 1000 patient-days and ADEs per 100 medication orders written

\begin{tabular}{lllll}
\hline Reference & Type of ICUs & $\begin{array}{l}\text { Method of } \\
\text { study }\end{array}$ & Description of method & $\begin{array}{l}\text { ADEs/1000 } \\
\text { patient- } \\
\text { days }\end{array}$ \\
\hline 5 & MICU, SICU & Trigger tool & $\begin{array}{l}\text { ADEs were identified by extraction from the } \\
\text { of ADE }\end{array}$ & $\begin{array}{l}\text { Injury resulting from } \\
\text { drug treatment }\end{array}$ \\
2.4 & screening of ICD codes and reviewing antidote
\end{tabular}

use and potentially drug-related electrolyte disturbances

2 MICU, 3 SICU

Multifaceted

Multifaceted
Charts were chosen randomly, and IHI trigger tool was applied using predesigned data collection forms. Charts were reviewed for

$20 \mathrm{~min}$, and if a trigger was detected only the portion of the chart relevant to it was reviewed. Severity of the adverse events was classified.

The ICU pharmacist analysed every medication order of randomly selected patients during study period.

Nurses and pharmacists were asked to report incidents using logs. A trained nurse visited each unit at least twice daily on weekdays and solicited information from staff concerning all actual or potential drug related incidents. A study nurse briefly reviewed all charts at least daily on weekdays.

Pump-related transaction data were obtained from smart pump log downloads. Log reports included pump alerts. In addition, error reports were collected by chart review, solicited staff reports, hospital incident reports and a computerised ADE surveillance monitor.

Nurses and pharmacists were asked to report incidents using logs. A trained nurse visited each unit at least twice daily on weekdays and solicited information from staff concerning all actual or potential drug related incidents. A study nurse briefly reviewed all charts at least daily on weekdays.

Two investigators identified incidents by review of medical records in which they examined all progress notes, orders and lab results. Pharmacist interventions were also tracked on a form.

Nurses and pharmacists were asked to report incidents using logs. A trained nurse visited each unit at least twice daily on weekdays and solicited information from staff concerning all actual or potential drug related incidents. A study nurse briefly reviewed all charts at least daily on weekdays.

Primary method of data collection was direct continuous observation. Voluntary and solicited reports were also used to identify incidents. Computerised ADE detection was also used to monitor events. Also, guided chart abstraction by trained research nurses was performed.

Nurses and pharmacists were asked to report incidents using logs, a trained nurse visited each unit at least twice daily on weekdays and solicited information from staff concerning all actual or potential drug related incidents, and a study nurse briefly reviewed all charts at least daily on weekdays.

Pump-related transaction data were obtained from smart pump log downloads. Log reports included pump alerts. In addition, error reports were collected by chart review, solicited staff reports, hospital incident reports and a computerised $\mathrm{ADE}$ surveillance monitor
Medication related adverse event

Medication prescribing errors that cause harm to patient

A preventable injury resulting

from medical intervention related to a drug

Injury due to a medication

Injury resulting from medical intervention related to a drug

Injury related to use of a medication

An injury resulting from 33 the administration of a drug

Any injury due to medical management rather than the underlying disease

PADE definition

PADEs/1000 patient-days

Incident with a potential 13.5 a drug

ME that had the potential 23.8 cause harm but did not because it either was intercepted before reaching the patient or reached the patient and because of luck did not cause harm 
Table 2 Continued

\begin{tabular}{|c|c|c|c|c|c|}
\hline Reference & Type of ICUs & $\begin{array}{l}\text { Method of } \\
\text { study }\end{array}$ & Description of method & $\begin{array}{l}\text { Definition } \\
\text { of ADE }\end{array}$ & $\begin{array}{l}\text { ADEs/1000 } \\
\text { patient- } \\
\text { days }\end{array}$ \\
\hline \multirow[t]{2}{*}{13} & Surgical/trauma ICU & Trigger tool & $\begin{array}{l}\text { All patients admitted during a 3-month period } \\
\text { were monitored for abnormalities in their } \\
\text { potassium, magnesium, liver enzymes, blood } \\
\text { glucose, serum creatinine and platelet count. } \\
\text { Once identified, they were categorised as } \\
\text { possibly, probably or definitely caused by } \\
\text { a drug used in the patient. They were also } \\
\text { classified in terms of severity on a scale from } \\
\text { no change in outcome to death. }\end{array}$ & $\begin{array}{l}\text { Drug-related hazardous } \\
\text { condition: a biochemical } \\
\text { response to a drug that } \\
\text { has the potential to } \\
\text { cause clinical injury }\end{array}$ & $\begin{array}{l}47 \mathrm{DRHCs} / \\
1000 \\
\text { patient-days }\end{array}$ \\
\hline & & & & Definition of $A D E$ & $\begin{array}{l}\mathrm{ADEs} / 100 \\
\text { orders }\end{array}$ \\
\hline 14 & Mixed PICU & $\begin{array}{l}\text { Observation of entire } \\
\text { medication process }\end{array}$ & $\begin{array}{l}\text { One nurse was picked randomly at the start of } \\
\text { each shift and followed to observe } \\
\text { prescriptions from writing to administration }\end{array}$ & Not provided & 3.6 \\
\hline 15 & Mixed ICU & $\begin{array}{l}\text { Observation of entire } \\
\text { medication process }\end{array}$ & $\begin{array}{l}\text { Two pharmacy residents recorded activities } \\
\text { related to medication use process using } \\
\text { standardised data collection sheets. The } \\
\text { observers followed the entire medication } \\
\text { process from prescription writing to } \\
\text { administration. }\end{array}$ & $\begin{array}{l}\text { An injury or patient harm } \\
\text { occurring as the result of } \\
\text { a medication } \\
\text { intervention; can be } \\
\text { preventable or non- } \\
\text { preventable }\end{array}$ & 4.3 \\
\hline
\end{tabular}

CCU, critical care unit; CSICU, cardiac surgery intensive-care unit; ICU, intensive care unit; ME, medication error; MICU, medical intensive care unit; PICU, paediatric intensive care unit; SICU surgical intensive care unit.

preventable ADEs' or 'all events where treatment or observation differed from a planned one. 118

$\mathrm{ADE}$ was used as an outcome in 11 studies (table 2). ${ }^{15-12} 1415$ Although one study did not provide a definition for this term, ${ }^{14}$ nearly all the others had a common theme-patient injury. Nine of these definitions defined $\mathrm{ADE}$ as injury or harm caused by a medication, while one gave a vague definition of 'medicationrelated adverse event. ${ }^{6}$ Overall the concept of $\mathrm{ADE}$ among studies was more consistent than that for MEs. Nevertheless, it would still be useful to have a standard definition for an $\mathrm{ADE}$, as this would likely reduce the substantial variability in rates among studies.

The reason for this diversity of definitions is likely related to that fact that no standard definition is accepted by all the major organisations related to medication safety. For example, the IOM definition of ME is different from that of the National Coordinating Council for Medication Error Reporting and Prevention, while the Agency for Healthcare Research and Quality does not provide a definition for this term. Standardisation of definitions between these important groups would likely set a precedent for researchers in this area. The IOM definitions were used most commonly in papers included in this study, perhaps suggesting they may be accepted more readily by the research community.

\section{Variability in methods of detecting events}

In general, multifaceted methods for measuring events were associated with higher rates of event detection. However, when studies using multifaceted methods were compared, substantial differences in ME rates were found, varying from 18.6 to 146.1 per 1000 patient-days. ${ }^{1} 81216$ The studies which reported 18.6 and 22.1 MEs per 1000 patient-days did not include observation, whereas the studies that reported 129.5 and 146.1 MEs per 1000 patient-days included observation methods. ${ }^{181216}$ The study by Rothschild et al reported $129.5 \mathrm{MEs} / 1000$ patient-days, but only 37.6 ADEs/1000 patient-days, suggesting that the addition of observation may increase the sensitivity of detecting errors, but is not associated with an increased detection of harm. ${ }^{12}$

For $\mathrm{ADEs}$, rates in these studies ranged from 5.1 to $37.6 \mathrm{ADEs}$ per 1000 patient-days. ${ }^{18-12}$ Three of these studies used similar methods, involving voluntary and solicited incident reporting and daily chart review during weekdays. ${ }^{1} 911$ Despite this commonality, rates were 5.1, 14.4 and 33 ADEs per 1000 patientdays. $^{1} 911$ The study which reported $5.1 \mathrm{ADEs} / 1000$ patientdays included only preventable events, whereas the other two studies included all events that caused patient harm. ${ }^{1}$ The reason for variation between the latter two studies may be partly because the studies were done in different types of ICUs. ${ }^{911}$ The fourth study by Rothschild et al that reported 37.6 $\mathrm{ADEs} / 1000$ patient-days incorporated direct continuous observation into their methods, in addition to voluntary and solicited incident reporting and daily chart review during weekdays. ${ }^{12}$ This difference in methods used to detect adverse events likely accounts for the higher detection rate of the latter study.

Substantial variation in event rates was also seen with voluntary reporting methods. Reasons for this variation include the anonymity of reporting, the hospital safety culture, the staff education on incident reporting and the presence of a nonpunitive policy related to reporting. In six studies using voluntary reporting, which measured MEs/1000 patient-days, all reported having non-punitive incident reporting systems, and four out of these six papers described educational programmes for staff and strategies to encourage staff to report incidents. ${ }^{17-22}$ The error rates in these studies still ranged from 8.8 to $241 \mathrm{MEs} / 1000$ patient-days. ${ }^{17-22}$ Paradoxically, the study that reported $241 \mathrm{MEs} / 1000$ patient-days did not describe any intervention to encourage reporting, while the study that reported $8.8 \mathrm{MEs} / 1000$ patient-days described a strategy to encourage staff to report even trivial incidents. ${ }^{17} 22$ This paradox was likely related to the difference in terms used to define events. In the study reporting $8.8 \mathrm{MEs} / 1000$ patient-days, the definition of $M E$ was specific (ie, a dose of medication that deviates from the physician's orders which reaches the patient). ${ }^{17}$ Conversely, in the study reporting $241 \mathrm{MEs} / 1000$ patient-days, ME was defined much more broadly as a 'mistake made at any stage of the provision of a pharmaceutical product to a patient. ${ }^{22}$ Observation techniques involve study personnel watching nurses prepare and administer medications and recording any discrepancies from what is ordered in the patient's chart. The rates of observed errors in medication preparation and 
Table 3 Description of studies that presented rates of medication errors (MEs) per 1000 patient-days

\begin{tabular}{llll}
\hline Reference & Type of ICU & Method of study & MEs/1000 \\
\hline 1 & 2 MICU, 3 SICU & Multifaceted & $\begin{array}{l}\text { Nurses and pharmacists were asked to } \\
\text { report incidents using logs, a trained } \\
\text { nurse visited each unit at least twice daily }\end{array}$
\end{tabular}

solicited information

from staff concerning all actual or

potential drug-related incidents, and

a study nurse briefly reviewed all charts at

least daily on weekdays

8 2 CSICU, 2 CS stepdown

Multifaceted unit

(a)

12

MICU, CCU

Multifaceted

16

MICU, CCU

Multifaceted

17

NICU, PICU

Voluntary reporting

Voluntary reporting

20

MICU
Pump-related transaction data were obtained from smart pump log downloads. Log reports included pump alerts. In addition, error reports were collected by chart review, solicited staff reports, hospital incident reports and a computerised ADE surveillance monitor. Primary method of data collection was direct continuous observation. Voluntary and solicited reports were also used to identify incidents. Computerised ADE detection was also used to monitor events. Also, guided chart abstraction by trained research nurses was performed.

A team of two nurse chart reviewers and six physician observers collected data on errors made by interns, which was supplemented by voluntary reports and a computerised event-detection monitor

Written incident reports were submitted by persons who noticed the errors. All incident reports are reviewed anonymously by a pharmacy manager and possible corrective measures are discussed in monthly quality assurance meetings. The non-punitive nature of the review is emphasised, and ICU personnel are encouraged to send reports even when errors seem trivial. Patient injuries are classified on a 1-4 severity scale.

An incident registration form was developed without any patient ID except for sex and age. The person reporting was allowed to remain anonymous but the professional status was requested. The seriousness of the errors was evaluated by four ICU staff members. Prior to starting the reporting process, staff were informed of incident reporting during meetings and with the internal newsletter. They were asked to report errors no matter how small.

Errors were identified using critical incident forms. The forms were analysed monthly by a multidisciplinary risk management group and graded according to severity. Non-punitive system.

A locally developed, card-based reporting programme available to hospital physicians and staff. The SAFE card solicited core info about patient safety events and could be anonymous if desired. The intervention involved encouraging the non-punitive nature of the programme and open communication about safety.
Errors during ordering, transcribing, dispensing, administering or monitoring. These errors have the capacity to cause injury and reach the patient.

ME in ordering or execution of treatment, inadequate monitoring system or medication related failure to take precautions or follow protocol to prevent accidental injury

An ME that causes harm, or has the potential to cause harm, related to the ordering or administration of pharmaceutical agents, blood products or intravenous fluids

A dose of medication that deviates from the physicians' order as written in the medical record. Except for errors of omission, the medication dose must actually reach the patient to be considered an error.

\section{All events when} treatment or observation differed from a planned one, and when this was not a part of the natural course of the disease

Not provided

Not provided 64 
Table 3 Continued

\begin{tabular}{|c|c|c|c|c|c|}
\hline Reference & Type of ICU & Method of study & & Definition of ME & $\begin{array}{l}\text { MEs/1000 } \\
\text { patient-days }\end{array}$ \\
\hline 21 & 2 multidisciplinary ICUs & Voluntary reporting & $\begin{array}{l}\text { The research team attempted to } \\
\text { familiarise the staff with the concept of } \\
\text { incident reporting, and to describe the } \\
\text { non-punitive nature of the study. The } \\
\text { incident reporting form requested the } \\
\text { location, reporter's profession, type of } \\
\text { unintended event, severity of unintended } \\
\text { event and the time of day it was detected. }\end{array}$ & $\begin{array}{l}\text { Event that reduce or } \\
\text { could have reduced the } \\
\text { safety margin for the } \\
\text { patient while in the ICU. } \\
\text { Specifically, prescription } \\
\text { error, transcription error, } \\
\text { wrong dose and wrong } \\
\text { route of administration. }\end{array}$ & 90.9 \\
\hline 22 & Paediatric cardiac ICU & Voluntary reporting & $\begin{array}{l}\text { ME report forms were filled out and } \\
\text { analysed. Info collected: profession of } \\
\text { reporter, location of event, type of error } \\
\text { (supply, administration, prescription), } \\
\text { details of event, including clinical } \\
\text { consequences. Anonymous. Non-punitive. }\end{array}$ & $\begin{array}{l}\text { A mistake made at any } \\
\text { stage of in the provision } \\
\text { of a pharmaceutical } \\
\text { product to a patient }\end{array}$ & 241 \\
\hline 23 & ICU, PICU, NICU & Prescription review & $\begin{array}{l}\text { Pharmacists reviewed prescriptions for } \\
\text { therapy and prescription errors, and filled } \\
\text { out a standardised form when they were } \\
\text { found, which categorised their actions in } \\
\text { response to the error, and the clinical } \\
\text { significance of the error }\end{array}$ & $\begin{array}{l}\text { Therapy errors- incorrect } \\
\text { choice of drugs for } \\
\text { a defined disease, } \\
\text { incorrect drug because } \\
\text { of similarity in name or } \\
\text { interactions between } \\
\text { drugs prescription errors } \\
\text {-incorrect dosage, } \\
\text { route, frequency, patient, } \\
\text { or length of treatment }\end{array}$ & $\begin{array}{l}8.2 \\
(1.6=\text { clinically } \\
\text { significant } \\
\text { errors })\end{array}$ \\
\hline 24 & Multidisciplinary ICU & Prescription review & $\begin{array}{l}\text { A pharmacist reviewed the nursing MAR } \\
\text { for the previous } 24 \text { h period and compared } \\
\text { it with the physician's orders in the } \\
\text { patients chart and recorded all doses on } \\
\text { a patient data collection sheet. The } \\
\text { patient's TISS score was available for the } \\
\text { exact date/time of error, as were ICU } \\
\text { deaths. }\end{array}$ & $\begin{array}{l}\text { Drug administered to } \\
\text { wrong patient, wrong } \\
\text { dose, wrong medication, } \\
\text { wrong route of } \\
\text { administration, wrong } \\
\text { time, patient has allergy } \\
\text { to prescribed } \\
\text { medication, omission of } \\
\text { a medication, error in } \\
\text { infusion rate, improper } \\
\text { administration and } \\
\text { administration of the } \\
\text { wrong dosage form }\end{array}$ & $\begin{array}{l}497.5 \text { (no } \\
\text { mistakes } \\
\text { resulted in } \\
\text { significant } \\
\text { patient harm) }\end{array}$ \\
\hline 7 & SICU & Prescription review & $\begin{array}{l}\text { ICU pharmacist analysed every } \\
\text { medication order of randomly selected } \\
\text { patients during study period. An } \\
\text { independent panel evaluated the severity } \\
\text { of the events. }\end{array}$ & $\begin{array}{l}\text { Medication prescribing } \\
\text { errors: minor-no } \\
\text { potential to cause harm } \\
\text { intercepted-potential to } \\
\text { cause harm but } \\
\text { intercepted in time } \\
\text { serious-non-intercepted } \\
\text { potential ADEs (potential } \\
\text { to cause harm) and ADEs } \\
\text { (actually causes harm) }\end{array}$ & $\begin{array}{l}2344 \text { (all) } 519 \\
\text { (serious) }\end{array}$ \\
\hline 25 & MICU & $\begin{array}{l}\text { Observation of } \\
\text { medication } \\
\text { administration }\end{array}$ & $\begin{array}{l}\text { Pharmacy residents observed nurses' } \\
\text { administration of medications. The nurses } \\
\text { knew the purpose of the study. The length } \\
\text { of observation was } 5 \mathrm{~h} / \text { day, during the } \\
\text { heaviest period of medication preparation/ } \\
\text { administration. All observations were } \\
\text { noted, then later compared with original } \\
\text { physicians' orders, manufacturers' data } \\
\text { and data available in the literature. } \\
\text { Potential clinical significance was } \\
\text { evaluated by an ICU physician. }\end{array}$ & $\begin{array}{l}\text { Wrong drug preparation, } \\
\text { dose error, wrong } \\
\text { administration technique, } \\
\text { physicochemical } \\
\text { compatibility error }\end{array}$ & 1500 \\
\hline 21 & 2 multidisciplinary ICUs & $\begin{array}{l}\text { Observation of entire } \\
\text { medication process }\end{array}$ & $\begin{array}{l}\text { Two medical residents acted as } \\
\text { observers. They filled out standard form } \\
\text { during morning shifts for } 14 \text { days. The } \\
\text { form requested the location, reporter's } \\
\text { profession, type of unintended event, } \\
\text { severity of unintended event and the time } \\
\text { of day it was detected. The staff were } \\
\text { unaware of the observation. }\end{array}$ & $\begin{array}{l}\text { Event that reduce or } \\
\text { could have reduced the } \\
\text { safety margin for the } \\
\text { patient while in the ICU. } \\
\text { Specifically: problems } \\
\text { with medications: } \\
\text { prescription error, } \\
\text { transcription error, } \\
\text { wrong dose, wrong route } \\
\text { of administration }\end{array}$ & 78 \\
\hline
\end{tabular}

ADE, adverse drug event; ICU, intensive care unit; MAR, Medication Administration Record; SAFE, Safety, Actions, Focus Everyone; TISS, Therapeutic Intervention Scoring System.

administration varied substantially $(2.8,7 \%, 8.8 \%$ and $33.9 \%$ of the total number of nurses' activities) after wrong time errors were excluded. ${ }^{25-28}$ Although the techniques described in these four studies were similar, the definition of medication prepara- tion and administration errors differed. For instance, the study by Calabrese et al gave a vague definition ('any preventable event that may cause or lead to inappropriate medication use or patient harm'), ${ }^{26}$ while the study by Tissot et al gave a specific 
Table 4 Description of studies that presented errors as a percentage of observed medication preparations and numbers of drug administrations with errors

\begin{tabular}{|c|c|c|c|c|c|}
\hline Reference & Type of ICU & Method of study & Description of methods & $\begin{array}{l}\text { Preparation and } \\
\text { administration } \\
\text { error definition }\end{array}$ & $\begin{array}{l}\text { Percentage of } \\
\text { observations } \\
\text { with errors (wrong } \\
\text { time errors excluded) }\end{array}$ \\
\hline 26 & SICU, MICU, mixed ICUs & $\begin{array}{l}\text { Observation of medication } \\
\text { preparation and } \\
\text { administration }\end{array}$ & $\begin{array}{l}\text { Pharmacists at all by one involved } \\
\text { institutions did the observation. All } \\
\text { observers used the same definitions and } \\
\text { collected data on a standardised form. } \\
\text { Intravenous and oral medications were } \\
\text { included and only regularly scheduled } \\
\text { medications were monitored. Data } \\
\text { collection occurred twice daily, once in } \\
\text { the morning and once in the afternoon on } \\
\text { every patient in the ICU. Errors were } \\
\text { sorted based on type and patient } \\
\text { outcome. Nurses were not aware of the } \\
\text { observation. }\end{array}$ & $\begin{array}{l}\text { Any preventable event that } \\
\text { may cause or lead to } \\
\text { inappropriate medication use } \\
\text { or patient harm while the } \\
\text { medication is in the control of } \\
\text { the healthcare professional, } \\
\text { patient or consumer }\end{array}$ & $\begin{array}{l}2.8(1 \% \text { of errors resulted } \\
\text { in temporary harm) }\end{array}$ \\
\hline 25 & MICU & $\begin{array}{l}\text { Observation of medication } \\
\text { preparation and } \\
\text { administration }\end{array}$ & $\begin{array}{l}\text { Pharmacy residents observed nurses' } \\
\text { administration of medications. The nurses } \\
\text { knew the purpose of the study. The length } \\
\text { of observation was } 5 \text { h/day, during the } \\
\text { heaviest period of medication preparation/ } \\
\text { administration. All observations were } \\
\text { noted, then later compared with original } \\
\text { physicians' orders, manufacturers' data } \\
\text { and data available in the literature. } \\
\text { Potential clinical significance was } \\
\text { evaluated by an ICU physician. }\end{array}$ & $\begin{array}{l}\text { Wrong drug preparation, } \\
\text { dose error, wrong } \\
\text { administration technique, } \\
\text { physicochemical } \\
\text { compatibility error }\end{array}$ & $\begin{array}{l}7 \text { (no patient harm is } \\
\text { mentioned in study) }\end{array}$ \\
\hline 27 & NICU, PICU & $\begin{array}{l}\text { Observation of medication } \\
\text { preparation and } \\
\text { administration }\end{array}$ & $\begin{array}{l}\text { Pharmacy resident performed } 18-12 \mathrm{~h} \\
\text { shifts, half day and half night. The nursing } \\
\text { staff did not know the purpose of the } \\
\text { observation. The observer recorded each } \\
\text { medication dose, dosage form, frequency } \\
\text { and route of administration, and other } \\
\text { pertinent information on the monitoring } \\
\text { form. Intravenous fluids and prn } \\
\text { medications were not included in the } \\
\text { study, but intravenous infusions were. } \\
\text { The medications were recorded as } \\
\text { prepared and administered correctly or } \\
\text { incorrectly. When the drugs involved } \\
\text { were capable of causing potential serious } \\
\text { effects, the errors were classified as } \\
\text { 'serious.' }\end{array}$ & $\begin{array}{l}\text { Unauthorised dose, omitted } \\
\text { dose, wrong dose, wrong } \\
\text { route of admin, wrong rate of } \\
\text { administration, wrong } \\
\text { preparation of a dose, wrong } \\
\text { dosage form, wrong time of } \\
\text { administration ( }> \pm 30 \text { min } \\
\text { from scheduled time) }\end{array}$ & $\begin{array}{l}8.8 \text { (no patient harm } \\
\text { mentioned in study) }\end{array}$ \\
\hline 28 & Not specified & $\begin{array}{l}\text { Observation of medication } \\
\text { preparation and } \\
\text { administration }\end{array}$ & $\begin{array}{l}\text { Administration errors were detected by } \\
\text { using the disguised observation } \\
\text { technique; nurses were unaware of the } \\
\text { purpose of the study. A pharmacist } \\
\text { followed nurses preparing and } \\
\text { administering drugs in both hospitals on } \\
\text { five consecutive days from 07:00 to } \\
22: 00 \text {. All observations were noted on } \\
\text { data-collection forms and were compared } \\
\text { with actual medication orders afterwards. } \\
\text { Observations were also compared with } \\
\text { general nursing protocols. Errors were } \\
\text { categorised by type and severity. }\end{array}$ & $\begin{array}{l}\text { Any error in the preparation } \\
\text { and administration of drugs } \\
\text { by nurses, that is, a deviation } \\
\text { from written, printed or } \\
\text { verbal medication orders; } \\
\text { a deviation from drug } \\
\text { information sheets provided } \\
\text { by the manufacturer or from } \\
\text { the information in a handbook } \\
\text { on injectable drugs; or } \\
\text { deviation from general } \\
\text { nursing procedures used in } \\
\text { the hospital. }\end{array}$ & $\begin{array}{l}33.9 \text { (no patient harm } \\
\text { mentioned in study) }\end{array}$ \\
\hline
\end{tabular}

ICU, intensive care unit; Prn medication, medications as needed.

definition including 'wrong drug preparation, dose error, wrong administration technique and physicochemical compatibility error' (table 4). ${ }^{25}$ This wide variety of definitions could account in part for the diversity of error rates.

Studies that used prescription review showed that $2.2-11.2 \%$ of orders were associated with a ME (table 5). ${ }^{24}{ }^{29-31}$ All methods involved pharmacists reviewing prescriptions and recording errors identified. Studies that reported lower error rates $(2.2,5.4,5.9 \%)$ provided specific definitions of MEs, whereas the study by Ridley et al, reporting $11.2 \%$, used a more vague definition of 'prescriptions which did not follow standards given by the British National Formulary. ${ }^{24} 29-31$ When ME rates were reviewed, they were 8.2, 497.5 and 2344 per 1000 patient-days for the three prescription review studies that reported these data. ${ }^{7} 2324$ The methods used in two out of three studies were similar. ${ }^{723}$ The other study involved a pharmacist reviewing the medication administration record for the past $24 \mathrm{~h}$ and comparing it with doctors' orders. ${ }^{24}$ This difference, as well as the inconsistency in the definition of $\mathrm{ME}$ (table 3), may have contributed to the observed variation in rates.

\section{Recommendations for methods of tracking MEs and ADEs}

The IOM currently recommends different means of monitoring $\mathrm{ADEs}$ or MEs depending on what the institution hopes to achieve from the measurements. ${ }^{3}$ The recommendations are not specific for ICUs. If the institution wishes to track errors resulting in 
Table 5 Description of studies that presented percent of orders written with a medication error (ME) or adverse drug event (ADE)

\begin{tabular}{|c|c|c|c|c|c|}
\hline Reference & Type of ICU & Method of study & Description of methods & ME definition & $\begin{array}{l}\text { Percentage of orders } \\
\text { with an ME }\end{array}$ \\
\hline 24 & Multidisciplinary ICU & Prescription review & $\begin{array}{l}\text { A pharmacist reviewed the nursing MAR } \\
\text { for the previous } 24 \text { h period and compared } \\
\text { it with the physician's orders in the } \\
\text { patients chart and recorded all doses on } \\
\text { a patient data collection sheet. The } \\
\text { patient's TISS score was available for the } \\
\text { exact date/time of error, as were ICU } \\
\text { deaths. }\end{array}$ & $\begin{array}{l}\text { Drug administered to wrong patient, } \\
\text { wrong dose, wrong medication, wrong } \\
\text { route of administration, wrong time, } \\
\text { patient has allergy to prescribed } \\
\text { medication, omission of a medication, } \\
\text { error in infusion rate, improper } \\
\text { administration, administration of the } \\
\text { wrong dosage form }\end{array}$ & $\begin{array}{l}2.2 \text { (none of these } \\
\text { resulted in significant } \\
\text { patient harm) }\end{array}$ \\
\hline 29 & General ICU & Prescription review & $\begin{array}{l}\text { Details of all MEs identified by the ICU } \\
\text { clinical pharmacist, in the course of his } \\
\text { normal prescription review, were } \\
\text { prospectively recorded. MEs were } \\
\text { assessed by type and patient outcomes. }\end{array}$ & $\begin{array}{l}\text { Prescribing decision or prescription } \\
\text { writing process resulted in either an } \\
\text { unintentional significant reduction in the } \\
\text { probability of treatment being timely and } \\
\text { effective or an unintentional significant } \\
\text { increase in the risk of harm when } \\
\text { compared with generally accepted } \\
\text { practice }\end{array}$ & $\begin{array}{l}5.4 \text { (no patient harm } \\
\text { mentioned) }\end{array}$ \\
\hline 30 & PICU & Prescription review & $\begin{array}{l}\text { ICU ward pharmacist recorded the } \\
\text { prescriptions determined to be in error, } \\
\text { noting type of error, drug and the person } \\
\text { who prescribed the drug. An ICU doctor } \\
\text { then classified the type and severity } \\
\text { errors. }\end{array}$ & $\begin{array}{l}\text { Dose error, intravenous compatibility } \\
\text { error, drug interaction, administration } \\
\text { error }\end{array}$ & $\begin{array}{l}5.9(0.5=\text { significant } \\
\text { error })\end{array}$ \\
\hline \multirow[t]{2}{*}{31} & Not specified & Prescription review & $\begin{array}{l}\text { All drug prescriptions were reviewed daily } \\
\text { during the study period and errors } \\
\text { identified by comparison with standards } \\
\text { given in the British National Formulary. } \\
\text { Errors were categorised by nature and } \\
\text { clinical outcome. }\end{array}$ & $\begin{array}{l}\text { Prescriptions which did not follow } \\
\text { standards given by the British National } \\
\text { Formulary were considered in error }\end{array}$ & $\begin{array}{l}11.2 \text { (no patient harm } \\
\text { mentioned) }\end{array}$ \\
\hline & & & & ADE definition & $\begin{array}{l}\text { Percentage of orders } \\
\text { written resulting in } \mathrm{ADE}\end{array}$ \\
\hline 32 & 9 PICUS & Prescription review & $\begin{array}{l}\text { MEs were detected using three levels of } \\
\text { surveillance. Pharmacists reviewed orders } \\
\text { before entering them into computer } \\
\text { system and the PICU nurse reviewed } \\
\text { orders before transcription. An oversight } \\
\text { team acted at each hospital to try and } \\
\text { standardise the process across the } \\
\text { hospitals involved }\end{array}$ & Not provided & 0.09 \\
\hline
\end{tabular}

$A D E$, adverse drug event; ICU, intensive care unit; $M E$, medication error.

ADEs, chart review, voluntary and prompted self-report systems, and computer-generated $\mathrm{ADE}$ tracking are key recommendations. ${ }^{3}$ However, if the institution wishes to detect as many errors as possible in order to identify system problems to be fixed, observation, in addition to chart review and voluntary and prompted self-report, is recommended. ${ }^{3}$ Although advantages and disadvantages of each method are discussed, no gold standard is presented as the best method for tracking MEs or ADEs.

Our study confirmed that observation methods are very sensitive for detecting MEs and would be useful for the reasons noted above. We found that multifaceted techniques seemed to provide the most consistent tracking of $\mathrm{ADEs}$, perhaps due to their rigorous nature of study. If the institution has the resources available to implement this type of approach, it seems quite useful in identifying errors associated with patient harm.

\section{Utility of this study}

The variability in error rates that we have observed in this review likely far outweighs the actual variation in MEs among ICUs. A recent review by Moyen et al confirms the frequency and severity of errors in the ICU, and confirms the importance of identifying system failures leading to MEs, so that these systems can be redesigned for improvement of patient outcomes. ${ }^{33}$ For this to occur reliably, standard definitions of MEs and ADEs must be adopted, and the methods for measuring rates of errors and adverse events should become standardised. These changes are also important in benchmarking these rates among different ICUs. There is a trend towards pay for performance healthcare currently; benchmarking may facilitate financial benefits for certain institutions if they have low event rates. All these reasons support the urgency to develop means for standardised reporting of MEs and ADEs.

\section{CONCLUSION}

There is wide variation in the definitions and rates of MEs and ADEs in ICUs, and in the methods used to detect them. Review of the literature showed that the $\mathrm{ADE}$ had a more reproducible definition than ME, as $\mathrm{ADE}$ denotes patient harm, while the interpretation of an ME can vary widely. Further standardisation of outcome definitions and methods of detecting errors must be done before the best methods for tracking ICU MEs and ADEs can be established.

Funding This work was funded by the Investigative Teams Program of the Michael Smith Foundation for Health Research (MSFHR), and NA is supported by a Scholar Award from the MSFHR.

Competing interests None.

Provenance and peer review Not commissioned; externally peer reviewed.

\section{REFERENCES}

1. Cullen DJ, Sweitzer BJ, Bates DW, et al. Preventable adverse drug events in hospitalized patients: a comparative study of intensive care and general care units. Crit Care Med 1997;25:1289-97.

2. Hussain E, Kao E. Medication Safety and transfusion errors in the ICU and beyond. Crit Care Clin 2005;21:91-110. 
3. Aspden P, Wolcott JA, Boatman LJ, et al, eds. Preventing medication errors quality chasm series. Washington, DC: The National Academic Press, 2007:4:237-45.

4. Franklin BD, Vincent C, Schachter M, et al. The Incidence of prescribing errors in hospital inpatients an overview of the research methods. Drug Saf 2005:28:891-900.

5. KaneGill S, Rea RS, Verrico MM, et al. Adverse-drug-event rates for high-cost and high-use drugs in the intensive care unit. Am J Health Syst Pharm 2006:63:1876-81.

6. Resar RK, Rozich JD, Simmonds T, et al. A trigger tool to identify adverse events in the intensive care unit. Jt Comm J Qual Patient Saf 2006;32:585-90.

7. Colpaert K, Claus B, Somers A, et al. Impact of computerized physician order entry on medication prescription errors in the intensive care unit: a controlled crosssectional trial. Crit Care 2006;10:R21.

8. Rothschild JM, Keohane CA, Cook EF, et al. A controlled trial of smart infusion pumps to improve medication safety in critically ill patients. Crit Care Med 2005;33:533-40.

9. Bates DW, Cullen DJ, Laird N, et al. Incidence of adverse drug events and potential adverse drug events: implications for prevention. JAMA 1995;274:29-34.

10. Leape LL, Cullen DJ, Clapp MD, et al. Pharmacist participation on physician rounds and adverse drug events in the intensive care unit. JAMA 1999;282:267-70.

11. Bates DW, Leape LL, Petrycki S. Incidence and preventability of adverse drug events in hospitalized adults. J Gen Intern Med 1993:8:289-94.

12. Rothschild JM, Landrigan CP, Cronin JW, et al. The critical care safety study: the incidence and nature of adverse events and serious medical errors in intensive care. Crit Care Med 2005:33:1694-700.

13. Kane-Gill SL, Dasta JF, Schneider PJ, et al. Monitoring abnormal laboratory values as antecedents to drug-induced injury. J Trauma 2005;59:1457-62.

14. Buckley MS, Erstad BL, Kopp BJ, et al. Direct observation approach for detecting medication errors and adverse drug events in a pediatric intensive care unit. Pediatr Crit Care Med 2007:8:145-52.

15. Kopp BJ, Erstad BL, Allen ME, et al. Medication errors and adverse drug events in an intensive care unit: direct observation approach for detection. Crit Care Med 2006:34:415-25

16. Landrigan CP, Rothschild JM, Cronin JW, et al. Effect of reducing interns' work hours on serious medical errors in intensive care units. N Engl J Med 2004;351:1838-48.

17. Raju TN, Kecskes S, Thornton JP, et al. Medication errors in neonatal and paediatric intensive-care units. Lancet 1989;2:374-76.
18. Flaatten $\mathbf{H}$, Hevroy 0 . Errors in the intensive care unit (ICU) experiences with an anonymous registration. Acta Anaesthesiol Scand 1999;43:614-17.

19. Simpson JH, Lynch R, Grant J, et al. Reducing medication errors in the neonatal intensive care unit. Arch Dis Child 2004:89:F480-2.

20. Osmon S, Harris CB, Dunagan WC, et al. Reporting of medical errors: an intensive care unit experience. Crit Care Med 2004:32:727-33.

21. Capuzzo M, Nawfal I, Campi M, et al. Reporting of unintended events in an intensive care unit: comparison between staff and observer. BMC Emerg Med 2005;5:3

22. Wilson DG, McArtney RG, Newcombe RG, et al. Medication errors in paediatric practice: insights from a continuous quality improvement approach. Eur J Pediatr 1998;157:769-74.

23. Lustig A. Medication error prevention by pharmacists-an Israeli solution. Pharm World Sci 2000;22:21-5.

24. Girotti MJ, Garrick C, Tierney MG, et al. Medication administration errors. Heart Lung 1987:16:449-53.

25. Tissot $\mathbf{E}$, Cornette $\mathrm{C}$, Demoly $\mathrm{P}$, et al. Medication errors at the administration stage in an intensive care unit. Intensive Care Med 1999;25:353-9.

26. Calabrese AD, Erstad BL, Brandl $\mathrm{K}$, et al. Medication administration errors in adult patients in the ICU. Intensive Care Med 2001;27:1592-8.

27. Tisdale JE. Justifying a pediatric critical care satellite pharmacy by medication error reporting. Am J Hosp Pharm 1986;43:368-71.

28. van den Bemt PML, Rijn R, Phj Gossen AA, et al. Frequency and determinants of drug administration errors in the intensive care unit. Crit Care Med 2002;30:846-50.

29. Shulman R, Singer M, Goldstone J, et al. Medication errors: A prospective cohor study of hand-written and computerised physician order entry in the intensive care unit. Crit Care 2005:9:R516-21.

30. Bordun LA, Butt W. Drug errors in intensive care. J Paediatr Child Health 1992:28:309-11.

31. Ridley SA, Booth SA, Thompson CM, et al. Prescription errors in UK critical care units. Anaesthesia 2004;59:1193-200.

32. Cimino MA, Kirschbaum MS, Brodsky L, et al. Child health accountability I. Assessing medication prescribing errors in pediatric intensive care units. Pediatr Crit Care Med 2004;5:124-32.

33. Moyen E, Camire E, Stelfox HT. Clinical review: medication errors in critical care. Crit Care 2008;12:208. 